\title{
Profit analysis of pig farming in rural comunities in Minahasa Regency of North Sulawesi
}

\author{
N. M. Santa* and E. Wantasen \\ Faculty of Animal Husbandry, Sam Ratulangi University, \\ Jalan Kampus - Bahu, Manado 95115 - Indonesia \\ *Corresponding E-mail: nansisanta@unsrat.ac.id
}

Received October 29, 2017; Accepted July 09, 2018

\begin{abstract}
ABSTRAK
Tujuan penelitian ini adalah menganalisis faktor-faktor yang mempengaruhi keuntungan usaha ternak babi di Kabupaten Minahasa berdasarkan orientasi penjualan output, yaitu menjual babi bibit dengan periode pemeliharaan 5 bulan (usaha pembibitan), dan menjual babi dewasa periode pemeliharaan 10 bulan (usaha kombinasi pembibitan-penggemukan). Penelitian dilaksanakan pada bulan Juli-Desember 2016, menggunakan metode survey. Teknik pengambilan sampel menggunakan metode multistage random sampling. Lokasi yang terpilih yaitu Kecamatan Sonder, Kecamatan Tombulu dan Kecamatan Kakas berdasarkan populasi ternak babi terbanyak, dengan responden yaitu peternak babi yang diambil secara acak sebanyak 100 responden. Variabel yang diukur yaitu keuntungan, harga jagung, harga konsentrat, harga dedak, harga obat-obatan, harga vitamin, penyusutan kandang, jumlah anak babi, pengalaman beternak dan orientasi penjualan output. Data dianalisis menggunakan fungsi keuntungan UOPCD dengan regresi linier berganda. Penelitian menunjukkan bahwa harga input faktor produksi dan jumlah anak babi secara bersama-sama berpengaruh nyata terhadap keuntungan $(\mathrm{P}<0.01)$. Secara parsial, harga jagung, harga konsentrat, harga dedak, jumlah anak babi dan orientasi penjualan output, berpengaruh nyata terhadap keuntungan $(\mathrm{P}<0.01)$. Rata-rata keuntungan usaha pembibitan sebesar Rp 942.823,70/bulan dan kombinasi pembibitan-penggemukan sebesar Rp 3.679.833,85/bulan, dengan rata-rata kepemilikan induk berjumlah 2,25 ekor.
\end{abstract}

Kata kunci : keuntungan, orientasi penjualan output, pembibitan, penggemukan, ternak babi

\begin{abstract}
The objective of this study was to analyze the factors influencing the profit of pig farms in rural communities in Minahasa Regency, North Sulawesi based on output sales orientation for breeding stock and combination of breeding-fattening models. The research was conducted from July to December 2016, using survey method with multistage random sampling technique. The selected locations were three Districts of Sonder, Tombulu and Kakas based on the largest population of pigs involving randomly one hundred respondents. The variables were included profit, prices of corn, concentrate, bran, medicine, vitamin, animal housing depreciation, the number of piglets, farm experience and output sales orientation. Data were analyzed on the basis of unit output price Cobb-Douglas Profit Function using multiple linear regressions. Research showed that input prices of production factor and number of piglets were influenced profit $(\mathrm{P}<0.01)$. Partially, the input prices of corn, concentrate, bran, medicine, vitamins, output sales orientation, and the number of piglets influenced profit $(\mathrm{P}<0.01)$. Average profits of farm were IDR 942,823.70/month for breeding models and IDR 3,679,833.85/month for combination of breeding-fattening models, with average numbers of sows were 2.25 heads
\end{abstract}

Keywords: breeding, fattening, output sales orientation, pigs, profit 


\section{INTRODUCTION}

Pig farming is one of the potential livestock business developed in Minahasa Regency of North Sulawesi. The highest number of animal population among the other livestock is indicated by many pigs maintained by people in Minahasa. In addition, communities in Minahasa regency of North Sulawesi were potential as consumer of pork indicated by Christian population of more than $60 \%$ (Central Bureau of Statistics of North Sulawesi, 2016).

Pig farming in rural communities in Minahasa Regency was largely livestock business of community; however, the management was still conducted under traditional system. Traditional management systems were commonly found in rural areas of Indonesia (Kalangi et al., 2016; Prasetyo et al., 2012) included pig farming (Iyai et al., 2011; Iyai et al., 2013). The Ministry of Agriculture (2011) stated that the weakness of small-scale livestock business development, that was caused environmental pollution.

Pigs could be raised with three period categories : 1) farrow-to-finish); 2) feeder-tofinish; 3) farrow-to-feeder. There was also a combination of these three categories of swine production. Pig farms at rural areas of Minahasa Regency, were handling with two model categories based on output sales orientation. There were farmers who sold weaning piglets, and also farmers that sold adult pigs. Both categories of business were included in the category of pig business (Sihombing, 2006). In this study, the farmer's orientation selling weaning piglets were referred to a breeding models (farrow-to-feeder). Therefore, the period was about 5 months since the sows mated. The farmer that sold adult pigs, were started from piglet period to fattening period for 5 months when it reaches ideal weight and ready for sale, called a combination of breedingfattening models (farrow-to-finish). Both business models were conducted by pig farmers at rural areas in Minahasa Regency.

Pig farmers in rural areas in Minahasa Regency, in addition to trying to meet the needs of consumer meat, as potential consumers of pork, also aimed to increase the family income. Success in pig farms, both breeding and breedingfattening business, was known based on the amount of profit earned. In other words, profit was the main goal in pig farms.

There were several studies related to pig farming, although not specifically about the profit of pig farms. Adetunji and Adeyemo, (2012) explained that stocking cost, feed cost and labor cost had positive significant effects on the production output. Soltész et al. (2013) stated that the total income was mostly affected by the number of piglets per litter, price of piglet feed, and feed consumption of piglet. Research on the combination of breeding-fattening business had been studied by Warouw et al. (2014), Kueain et al. (2017), Uboegbulam and Naong, (2017).

Research on factors affecting the profitability of rural pig farms, by differentiating of breeding and combination of breedingfattening business, had not been well documented. The results of this study were expected to be a source of information for rural communities planning for pigs farming by choosing the most profitable type of business, either the breeding or a combination of breeding-fattening.

Based on this background, this research was aimed to analyze the factors influencing the profit of pig farming and the factors influencing it, based on two business category models of the breeding and the combination of breedingfattening model.

\section{MATERIALS AND METHODS}

\section{Sampling Methods and Data Collection}

The study was conducted in Minahasa Regency using a survey method. The determination of the study was used multistage random sampling method (Silalahi, 2015). The first stage was selecting districts having the highest population of pig farming, located in districts of Sonder, Tombulu and Kakas. In the second stage, two villages were selected with the most pig farming located at Villages of Kauneran and Tonelet in Sonder District; Villages of Koka and Kembes in Tombulu District and Villages of Tonelet and Paslaten in the Kakas District. The third stage was to obtain 100 farmers as respondents by using proportional random sampling method. Samples were randomly selected from the total of 40 farmers at Villages of Kauneran and Tonelet, 40 farmers at Villages of Koka and Kembes and 20 farmers at Villages of Tonelet and Paslaten.

The primary and secondary data were collected by questionnaire and interview method. The questionnaire was used to identity the respondents, input and output of pig farming. The secondary data were taken from Department of Agriculture in Minahasa Regency and also from 


\section{Data Analysis}

The data were analyzed using linier regression analysis of pig farming. The profit and the factors influencing the model were analyzed using Cobb-Douglas profit function (Soekartawi, 2002; Winarno, 2009) and Eviews version 9. In the Unit Output Price (UOP) Profit Function, it was stated that the optimal use of variable production factors was obtained by dividing profit with production unit price (Haloho et al., 2013). The type of profit function was analyzed using the derived from Cobb Douglas profit function. This type of function was known as Unit Output Price Cobb Douglas Profit Function (UOPCDPF) and transformed into a natural logarithm form (Haloho et al., 2013; Mandaka and Hutagaol, 2005) as follows:

$\ln \pi^{*}=\ln A^{*}+\sum_{1}^{6} \alpha_{i}^{*} \cdot \ln W_{i}^{*}+\sum_{1}^{2} \beta_{j}^{*} \cdot \ln Z_{j}^{*}+\gamma \cdot D_{o}$

Where:

$\pi^{*} \quad$ : normalized farmers' profit (IDR/period)

$\mathrm{W}_{1}{ }^{*}$ : normalized price of corn (IDR/kg)

$\mathrm{W}_{2}{ }^{*}$ : normalized price of bran (IDR/kg) $\mathrm{W}_{3}{ }^{*}: \begin{gathered}\text { normalized } \\ (\mathrm{IDR} / \mathrm{kg})\end{gathered}$ price of concentrate

$\mathrm{W}_{4}{ }^{*}$ : normalized price of medicine (IDR/kg)

$\mathrm{W}_{5}{ }^{*}$ : normalized price of vitamin (IDR/kg)

$\mathrm{W}_{6}^{*}$ : normalized the animal housing depreciation (IDR/period)

$\mathrm{Z}_{1} \quad$ : the number of piglet (head)

$\mathrm{Z}_{2} \quad$ : farm experience (years)

$\alpha_{i}^{*} \quad$ : coefficient of variable input

$\beta_{\mathrm{j}}^{*} \quad$ : coefficient of fix input

$\gamma \mathrm{D}_{\mathrm{O}}$ : coefficient of dummy variable output sales orientation

$\mathrm{D}_{\mathrm{O}}=1$, for breeding and $\mathrm{D}_{\mathrm{O}}=0$ for combination breeding-fattening model

The next phase, the test of the accuracy of the models was conducted by calculating the values of R-Square, F-test and t-test.

\section{Characteristics of Respondents}

Pig business in Minahasa Regency was a side business based on the amount of time allocation of work for about 2 hours per day. Pigs were kept in cages, and mostly managed (clean the cages and feed the animals) by women household every day in the morning and evening. Breeders used commercial feed in the form of corn, bran, concentrate and granules obtained from feed stores. Thus, pig farms in Minahasa Regency were classified as traditional pig farming (Mubyarto, 2001). Furthermore, pig wastes were not well treated by farmer, but those were usually dumped into the river.

The characteristics of pig farmers in Minahasa Regency were described in Table 1. It was known that the average number of sows in Minahasa Regency were 2.25 heads-with 24 heads of piglets or about 11 piglets per sow. Based on the data, it was known that the rural communities of pig farming were shown by the pig farming characteristics.

\section{Total Revenue}

Total outcome of pigs was calculated on the basis of the multiplication of the average pig weight (kg) obtained by weighing all the weaning piglets as well as the fattening pigs with the price of pigs (IDR $/ \mathrm{kg}$ ). The average number of weaning piglets weighed about 15.00 kilograms, while the weight of pigs was about 95.00 kilograms (Table 2 ). The average selling price of weaning piglet was about IDR 400,000-600,000/head adjusted to the total of body weight. The average price of fattening pigs was about IDR 18,000/kg body weight. Based on Table 3, it was known that the average of revenue on breeding model was IDR $9,808,366.67 /$ period or IDR $1,961,673.33 /$ month, whereas the combined model was IDR $51,435,157.83 /$ period or IDR 5,143,515.78/month. This situation explained that the amount of revenue in combination breeding-fattening model was higher than those in the breeding model.

\section{Cost of Production}

The production cost of pigs in Minahasa Regency covered fixed costs and variable costs. Fixed costs consisted of cage costs and equipment and feed costs. In this study, pig farms were generally using semi-permanent cages used for over 10 years. Therefore, the cost of the enclosure including equipment was calculated on the basis 
Table 1. Characteristics of Pig Farming in Minahasa Regency

\begin{tabular}{lcccc}
\hline \multirow{2}{*}{\multicolumn{1}{c}{ Pig Farming Characteristic }} & \multicolumn{3}{c}{ Districts } & \multirow{2}{*}{ The Average } \\
\cline { 2 - 4 } & Sonder & Tombulu & Kakas & \\
\hline The number of sow (head) & 2.43 & 2.43 & 1.90 & 2.25 \\
The number of piglet (head) & 25.53 & 25.34 & 21.10 & 23.99 \\
The litter size (head) & 10.5 & 10.42 & 11.10 & 10.67 \\
The piglet weaning weight (kg) & 16.00 & 15.00 & 14.00 & 15.00 \\
The pig weight (kg) & 96.00 & 95.00 & 94.00 & 95.00 \\
\hline
\end{tabular}

Table 2. Total Revenue, Cost of Production and Profit of Pig Farming in Minahasa Regency Based On Output Sales Orientation

\begin{tabular}{|c|c|c|c|c|c|c|}
\hline \multirow{3}{*}{ Variable } & \multicolumn{6}{|c|}{ District } \\
\hline & \multicolumn{2}{|c|}{ Sonder } & \multicolumn{2}{|c|}{ Tombulu } & \multicolumn{2}{|c|}{ Kakas } \\
\hline & Breeding & Combination & Breeding & Combination & Breeding & Combination \\
\hline & & -------------------' & -----IDR/ & /period----------- & ----------------' & ---- \\
\hline $\begin{array}{l}\text { Total } \\
\text { Revenue }\end{array}$ & $9,974,600.00$ & $53,487,741.67$ & $9,587,500.00$ & $56,169,381.82$ & $9,863,000.00$ & $44,648,350.00$ \\
\hline $\begin{array}{l}\text { Animal } \\
\text { Housing } \\
\text { depreciation }\end{array}$ & $400,000.00$ & $625,000.00$ & $394,444.44$ & $584,090.91$ & $375,000.00$ & $475,000.00$ \\
\hline Pig breeder & $120,000.00$ & $187,500.00$ & $254,444.44$ & $175,227.27$ & $112,500.00$ & $142,500.00$ \\
\hline $\begin{array}{l}\text { Total Fix } \\
\text { Cost of }\end{array}$ & $520,000.00$ & $812,500.00$ & $648,888.88$ & $759,318,18$ & $487,500.00$ & $617,500.00$ \\
\hline Corn & $1,824,026.25$ & $4,869,120.30$ & $1,690,743.06$ & $4,914,293.05$ & $1,870,211.40$ & $4,626,965.78$ \\
\hline Bran & $709,896.98$ & $1,793,007.50$ & $1,357,898.42$ & $1,444,841.59$ & $755,917.76$ & $1,666,890.00$ \\
\hline Concentrate & $1,435,110.80$ & $3,088,098.33$ & $865,201.51$ & $2,997,083.82$ & $1,389,490.00$ & $2,979,270.00$ \\
\hline Granules & $376,794.38$ & $1,198,720.00$ & $576,496.50$ & $2,844,661.19$ & - & $1,130,960.00$ \\
\hline Vitamin & $9,077.02$ & $126,170.54$ & $9,077.02$ & $269,117.65$ & $153,883.45$ & $210,033.60$ \\
\hline Mineral & - & $376,631.67$ & $58,333.36$ & $478,188.45$ & - & $262,889.30$ \\
\hline Medicine & $185,000.00$ & $2,166,833.33$ & $138,197.78$ & $2,590,863.64$ & $221,000.00$ & $1,686,500.00$ \\
\hline $\begin{array}{l}\text { Total Variable } \\
\text { Cost }\end{array}$ & $4,539,905.42$ & $13,618,581.68$ & $4,695,947.65$ & $15,539,049.39$ & $4,390,502.61$ & $12,563,508.68$ \\
\hline $\begin{array}{l}\text { Total Cost of } \\
\text { Production }\end{array}$ & $5,059,905.42$ & $14,431,081.68$ & $5,344,836.54$ & $16,298,367.57$ & $4,878,002.61$ & $13,181,008.68$ \\
\hline Profit/Period & $4,914,694.58$ & $39,056,659.99$ & $4,242,663.46$ & $39,871,014.25$ & $4,984,997.39$ & $31,467,341.33$ \\
\hline
\end{tabular}


of the cost of animal housing depreciation. Furthermore, the sow was mated naturally using boar. The situation was agreed with the study of Santa et al. (2017) found that pig farms in Tombulu District of Minahasa Regency did not apply artificial insemination due to lack of skill and information. Variable costs consisted of feed costs (corn feed, concentrate, and granules), the cost of vitamins and minerals, and the cost of animal medicines. The average production cost of breeding model was IDR 5,094,248.19/period or IDR $1,018,849.64 /$ month, whereas the combined model was IDR 14,636,819.31/period or IDR $1,463,681.93 /$ month.

\section{Profit}

The profits of pig farm in Minahasa Regency were different based on output orientation. Based on Table 3, the average amount of profit of pig breeding model were IDR 5,266,248.11/period or IDR 942,823.70/month, whereas the combinations of breeding-fattening model were IDR $37,528,111.25 /$ period or IDR 3,679,833.85/month.

\section{Analysis of Factors Affecting Profit in Pig Farming}

Factors influencing the profit of pig farming in Minahasa Regency, were analyzed using Eviews 9 with multiple linear regression model. The result of analysis is presented in Table 4.

The independent variables (corn price, bran price, concentrate price, vitamin price, mineral price, medicinal price, animal housing depreciation, number of piglets and farm experience) significantly affected $(\mathrm{P}<0.01)$ the pig farming profits. The R-Square value indicates that $97.33 \%$ of the variation of the dependent variable was explained by the variation of the independent variables, and only $2.66 \%$ were explained by other variables in the model.

\section{a. Input Price Factors}

Regression coefficient of corn price variable was -0.3681 that means if corn price increased $10 \%$, then profit would decrease equal to $3.681 \%$. Corn price $(\mathrm{X} 1)$ had a very significant effect $(\mathrm{P}$ $<0.01)$ to the profit of pig farming $(\mathrm{Y})$. The regression coefficient of bran price variable was -0.2581 . It meant that if bran price increased $10 \%$ hen the profit would decrease $2.581 \%$. Bran price (X2) had significant effect $(\mathrm{P}<0.1)$ to the profit of pig farming $(\mathrm{Y})$. The coefficient of regression of concentrate price was 1.1207 that means if the concentrate price increased $10 \%$, the profit decreased about $11.207 \%$. Concentrate price (X3) had significant effect $(\mathrm{P}<0.05)$ on the profit of pig farming (Y). Price of corn and bran had a significant negative effect to the profit of pig business. The availability and feed price of production factors, can not be controlled by farmer. If the price of corn and bran increased it would affect the cost, productivity and income of farming (Suratiyah, 2002). The situation was in accordance with several studies (Kalangi et al., 2016, Prasetyo et al., 2012) that found the increase of input prices having a negative effect on the profitability of livestock business. The price of concentrate had a significant positive effect on the profit of pig farming-that was different from others price factor. The situation causing concentrate feed was a kind of reinforcing feed not used by all breeders.

\section{b. The Number of Piglet}

The regression coefficient of variable number of piglets was 2.0237 , it means that if the number of piglets increased up to $10 \%$, the profit would also increase by $20.237 \%$. The number of piglets $(X 7)$ had a very significant effect ( $P$ $<0.001$ ) on the profit of pigs $(\mathrm{Y})$. Table 1 shows that the average number of piglets was 10.67 heads. The number of piglets (litter size) was related to the reproduction of the sows and the ability of the sow suckling the piglet (Sihombing, 2006). The breed of pig in this study was Hampshire. According to Sihombing (2006), Hampshire could have litter size as many as 14 piglets/sow. The number of piglets owned by farmers in Minahasa Regency, was below the average number litter size. These conditions might be caused by the breeder that was never done artificial insemination in pigs, to increase the genetic variation of pigs. Based on information from the Provincial Agriculture Office of North Sulawesi, over the past 20 years, the procurement of pigs was taken from outside the province of North Sulawesi. Efforts to increase litter size had increased farmers income. According to Soltész et al. (2013), the total income was mostly influenced by the litter size.

\section{c. Animal Housing Depreciation}

The regression coefficient of animal housing depreciation was -0.2807 , it means that if the cost of animal housing depreciation increased $10 \%$, the profit decreased about $2.807 \%$. Animal housing depreciation (X6) had significant effect $(\mathrm{P}<0.1)$ on the profit of pig business (Y). Depreciation cost of animal housing was calculated as the total cost of the housing constructed divided by the useful life of it. The 
results showed that, the increase in the cost of housing depreciation could decrease the profit. It was theoretically acceptable because the increasing of costs could also decrease the profit (Soekartawi, 2002). The animal housing was related to the total of pig owned. If farmers plan to increase the number of livestock, then first factor must be prepared was the cage.

\section{d. Dummy Variable of Output Sales Orientation}

The regression coefficient of output sales orientation were -2.0387 , it means that the profit of breeding model was lower about $2.0387 \%$ than that of the combination breeding-fattening model. The output sales orientation (X9) had a very significant effect $(\mathrm{P}<0.001)$ on the profit of pig farming (Y). The results were in accordance with the results of the research in Table 3. The profit of pigs farming in combination of breeding-fattening model were IDR 3,679,833.85/month that was higher than those in breeding model (IDR 942,823.70/month). Pig breeding model, mostly implemented by rural farmers in Minahasa Regency, because that farmers did not have enough money to convert into a model of combination breeding-fattening. This was in accordance with the average production cost for the model of combination breeding-fattening (IDR 14,636,819.31/period) that was higher than those of the breeding model (IDR $5,094,248.19 /$ period). In addition, the velocity of money on breeding model, was lower than the combination model.

\section{CONCLUSION}

Factors affecting the profit of pig farming were the prices of corn, bran, concentrate, animal housing depreciation and the number of piglets. The profit of pigs farming with combination model (IDR 3,679,833.85/month) was higher than breeding model (IDR 942,823.70/month).

\section{REFFERENCES}

Adetunji, M.O and K.E. Adeyemo. 2012. Economic Efficiency of Pig Production in Oyo State, Nigeria, A Stochastic Production Frontier Approach. Am. J. of Exp. Agric. 2(3): 382-394.

Central Bureau of Statistics North Sulawesi. 2016. http://sulut.bps.go.id/

Central Bureau of Statistics Minahasa Regency. 2016. http://minahasa.bps.go.id/
Haloho, R. D, S.I. Santoso, S. Marzuki, W. Roessali and A. Setiadi. 2013. Profit Function Analysis of Dairy Cattle Farming In Getasan And West Ungaran Districts, Semarang Regency. J. Indonesian Trop. Anim. Agric. 38(2):116-122.

Iyai, D. A., B.W. I. Rahayu, I Sumpe and D. Saragih. 2011. Analysis of pig profil on small-scale pig farmers in Manokwari, West Papua. J. Indonesian Trop. Anim. Agric. 36:190-197.

Iyai, D.A., O. Marani, T. Marjen and L. Usior. 2013. Pig farming performances of three Papuan Tribes: Case study of Byak, Onate and Arfak Tribes in Papua Barat. J. Indonesian Trop. Anim. Agric. 38(1):55-64.

Kalangia, L.S, Y. Syaukat, S.U. Kuntjoro and A. Priyanti. 2016. Factors affecting profit analysis of beef cattle farming in East Java, Indonesia. Livest. Res. Rural Dev. 28(12):Article\#226.

Kueain, Y.A, I.K. Suamba and P.U. Wijayanti. 2017. Analisis finansial usaha peternakan babi (Studi kasus peternakan babi UD Karang di Desa Jagapati, Kecamatan Abiansemal, Kabupaten Badung). J. Agri. Agro. 6(1): 96-104.

Mandaka, S. and M.P. Hutagaol. 2005. Profit function analysis, economic efficiency and credit scheme for development possible business scale people's dairy farm in the Kebon Pedes, City of Bogor. Agro Economic J. 23(2):191-208.

Mubyarto. 2001. Pemberdayaan Ekonomi Rakyat dan Peranan Ilmu-Ilmu Sosial. Yogyakarta : BPFE.

Prasetyo, E, Sunarso, P.B. Santosa and E. Rianto. 2012. The Influence of agribusiness subsystem on beef cattle fattening farm's profit in Central Java. J. Indonesian Trop. Anim. Agric. 37 (2):121-126.

Santa, N.M., M.A.V. Manese, J.E. Rawis, 2017. Tingkat Penerapan Teknologi Peternakan Babi di Kecamatan Tombulu Kabupaten Minahasa. Prosiding Seminar Nasional Peternakan 3, Fakultas Peternakan Universitas Hasanuddin Makasar, 18 September, 2017. P. 299-306

Sihombing, D.T.H. 2006. Ilmu Ternak Babi. Universitas Gadjah Mada Press. Yogyakarta.

Silalahi, U. 2015. Metode Penelitian Sosial Kuantitatif. Refika Aditama. Bandung

Soekartawi. 2002. Prinsip Dasar Ekonomi Pertanian. Penerbit PT Raja Grafindo 
Persada, Jakarta.

Soltész, A, S. Szőke and P. Balogh. 2013. Analysis of economic risks in sow Production. J. Agric. Inform. 4(2):10-21.

Suratiyah, K. 2002. Ilmu Usahatani. Penebar Swadaya. Jakarta.

Uboegbulam, G. C. and T.M. Naong. 2017. Swine marketing model and profit maximization in free state of South Africa. Inter. J. Man.
App.Sci. 3(1) 84-94.

Warouw, Z, V.V.J. Panelewen and Mirah (2014). Analisis usaha peternakan babi pada perusahaan "Kasewean" Kakaskasen II Kota Tomohon. J. Zootek. 34 (1):92-102.

Winarno, W.W. 2009. Analisis Ekonometrika dan Statistika Dengan Eviews. Edisi 4. UPP STIM YKPN 